\title{
Beelmateriaal gezocht
}

U hebt het misschien al opgemerkt. Elk jaar brengen we een nieuwe foto op de cover van het tijdschrift. En ook op de interactieve website zal er meer beeldmateriaal verschijnen. Soms zegt een foto meer dan een dik artikel!

We willen $u$ als lid vragen actief beeldmateriaal te verzamelen om het tijdschrift en de website te illustreren. Hebt $u$ een camera, dan vragen we $u$ om de typische leersituaties in uw eigen onderwijsomgeving vast te leggen. De foto die $\mathrm{u}$ instuurt kan gaan over het basiscurriculum en de vervolgopleiding, over een training of een consult. Misschien hebt $\mathrm{u}$ wel een beeld van het hidden curriculum. Ook zelfgemaakte tekeningen en cartoons zijn welkom. Wij zullen de beelden gebruiken in diverse toepassingen. $\mathrm{U}$ kunt uiteraard de door $\mathrm{u}$ gewentse toepassing aangeven. Gedigitaliseerde beelden kunt $\mathrm{u}$ elektronisch opsturen via een doorklik op onze website. Daar vindt u ook de technische specificaties.

De redactie van TMO 